\title{
EFIKASI CAMPURAN MINYAK CENGKEH DAN EKSTRAK BIJI MIMBA UNTUK PENGENDALIAN PENYAKIT KARAT (PHAKOPSORA PACHYRHIZI) PADA KEDELAI (GLYCINE MAX)
}

\author{
Sumartini \\ Balai Penelitian Tanaman Aneka Kacang dan Umbi \\ Jl. Raya Kendalpayak Km 8. Malang, Jawa Timur \\ E-mail: sumartiniputut@yahoo.co.id
}

\begin{abstract}
Efficacy of clove oil and neem extract control rust (Phakopsora rapachyrhizi) disease on soybean (Glycine max). Rust is the major disease on soybean. It was widely spread in almost all soybean production areas in the world. Yield losses can reach $85 \%$. One of the control measured was sprayed with a mixture of clove oil and neem extract. The objective of the research was found the information of the clove oil and neem extract effectivity control soybean rust. The research consisted of two phases as followed: 1) the efficacy of clove oil and neem extract dilution control soybean rust disease. 2) the efficacy of clove oil, neem extract and soap berry (Sapindus rarak) extract control soybean rust disease. The research was conducted at Kendalpayak Experimental Station and the green house of Indonesian Legumes and Tuber Crops Research Institute, Malang District, in dry season of 2012 and 2013 respectively. The research was arranged in randomized block design. Treatments were various comparison between clove oil, neem extract and soap berry. Parameters observed were rust disease intensity and yield components. Results showed that a mixture of clove oil and neem extract with ratio of 60:40 (v:v) can inhibit rust disease intensity by $45 \%$ compared with control, increase the number of pods by $60 \%$ and preventing the yieldloss of $20 \%$. Furthermore, a mixture of clove oil, neem extract and berry soap (Sapindus rarak) with a 50:30:20 ratio (v:v:v) can inhibit rust disease intensity up to $28 \%$ and $24 \%$ in the field and green house respectively and prevent yield loss by $12 \%$.
\end{abstract}

Key words: clove oil, neem extract, rust disease, Sapindus rarak, soybean

\begin{abstract}
ABSTRAK
Efikasi campuran minyak cengkeh dan ekstrak biji mimba untuk pengendalian penyakit karat (Phakopsora pachyrhizi) pada kedelai (Glycine max). Penyakit karat merupakan penyakit utama pada kedelai. Penyebaran penyakit karat sangat luas, hampir ke seluruh daerah sentra produksi kedelai di dunia. Kehilangan hasil dapat mencapai 85\%. Salah satu cara pengendalian adalah penyemprotan dengan campuran minyak cengkeh dan mimba. Penelitian bertujuan untuk mendapatkan informasi mengenai efektifivitas campuran minyak cengkeh, mimba dan lerak. Penelitian terdiri atas dua tahap yaitu: (1) Efikasi campuran minyak cengkeh dan ekstrak mimba untuk pengendalian penyakit karat pada kedelai. (2) Efikasi campuran minyak cengkeh, ekstrak mimba, dan ekstrak lerak untuk pengendalian penyakit karat pada kedelai. Penelitian dilakukan di Kebun Percobaan Kendalpayak, dan rumah kaca, Balai Penelitian Tanaman Aneka Kacang dan Umbi (Balitkabi), Kabupaten Malang, pada musim kemarau tahun 2012 dan 2013. Rancangan yang digunakan adalah acak kelompok. Perlakuannya berbagai perbandingan antara minyak cengkeh, ekstrak mimba dan ekstrak lerak. Parameter yang diamati: intensitas penyakit karat dan komponen hasil. Hasil penelitian menunjukkan bahwa campuran minyak cengkeh dan ekstrak mimba dengan perbandingan 60:40 (v:v) dapat menghambat intensitas penyakit karat sebesar 45\% dibandingkan dengan kontrol, dapat meningkatkan jumlah polong isi sebesar 37\%, dan mencegah kehilangan hasil sebesar $20 \%$. Campuran minyak cengkeh, ekstrak mimba, dan ekstrak lerak dengan perbandingan 50:30:20 (v:v) dapat menghambat intensitas penyakit karat sampai $28 \%$ dan 24\% masing-masing di rumah kaca dan lapangan serta mencegah kehilangan hasil sebesar $12 \%$.
\end{abstract}

Kata kunci: kedelai, lerak, minyak cengkeh, mimba, penyakit karat

\section{PENDAHULUAN}

Kedelai merupakan sumber protein nabati yang relatif murah dan sangat populer di masyarakat luas. Dengan terus meningkatnya pertumbuhan penduduk, maka industri pangan juga semakin berkembang, termasuk pangan yang terbuat dari kedelai (tahu, tempe, susu, dan olahan lainnya). Menurut data dari Direktorat Akabi (2013) bahwa kebutuhan kedelai dalam negeri baru dipenuhi $35 \%$ dan sisanya dipenuhi dari kedelai 
impor. Dalam meningkatkan produksi kedelai terdapat beberapa hambatan, adalah terjadinya penyakit karat.

Di Indonesia, umumnya kacang-kacangan ditanam pada musim kemarau, termasuk kedelai, namun demikian, pada musim kemarau sering terjadi penyakit karat dengan kerugian yang ditimbulkan cukup besar. Penyakit karat (Phakopsora pachyrhizi) merupakan penyakit utama (Semangun, 2004; Monte, 2003). Penyakit karat telah tersebar luas di sentra produksi kedelai di dunia. Di Indonesia, penyakit karat terdapat di sentra produksi kedelai di Sumatera, Jawa, Bali, Nusa Tenggara Barat, Kalimantan, dan Sulawesi Selatan (Semangun, 2004). Gejala penyakit karat ditandai dengan munculnya bercak klorotik kecil yang tidak beraturan pada permukaan daun. Pada umumnya gejala karat muncul pada permukaan bawah daun, bercak tersebut kemudian berubah menjadi coklat atau coklat tua dan membentuk pustul. Pustul merupakan kumpulan uredium, pustul yang telah matang akan pecah dan mengeluarkan spora yang menyerupai tepung yang warnanya seperti karat besi. Tepung tersebut merupakan kantung-kantung spora yang disebut uredium dan berisi uredospora. Penyakit karat menyebabkan daun menjadi kering dan rontok sebelum waktunya. Stadium awal penyakit karat mungkin tidak dapat dibedakan dengan pustul bakteri atau embun bulu (downymildew).

Kehilangan hasil akibat penyakit karat pada kedelai dilaporkan dapat mencapai 40-90\% di Indonesia (Sudjono et al., 1985), 10-40\% di Thailand, serta 23$50 \%$ di Taiwan (Sinclair \& Shurtleff, 1980).

Penggunaan cengkeh merupakan salah satu cara pengendalian penyakit karat, cara ini mempunyai keuntungan karena dapat terdegradasi di alam, tidak menimbulkan ras-ras baru, dan tidak mengganggu kesehatan manusia (Kardinan, 2004).

Tepung dan minyak bunga cengkeh dapat menghambat pertumbuhan cendawan Phytophtora capsici, P. palmivora, P. lignosus, dan Sclerotium rolfsii (Manohara et al., 1993). Selain itu minyak cengkeh juga dapat menekan perkembangan patogen tanaman antara lain Fusarium oxysporum dan Rhizoctonia solani (Towaha, 2012).

Sumartini (2007) melaporkan bahwa ekstrak bunga cengkeh mampu menekan cendawan Phakopsora pachyrizi lebih efektif daripada bawang merah dan tembakau. Selanjutnya bahwa penyemprotan ekstrak bunga cengkeh 100/1000 (w/v) efektif menghambat perkembangan penyakit karat sampai $67,6 \%$. Semakin tinggi konsentrasi ekstrak bunga cengkeh semakin rendah jumlah uredium. Dengan menaikkan konsentrasi ekstrak bunga cengkeh 2-3 kali jumlah uredium turun menjadi 39-64\%. Penyemprotan minyak bunga cengkeh $(2 \mathrm{ml} / \mathrm{L})$ dengan frekuensi 5 hari sekali untuk pengendalian penyakit karat (P. pachyrhizi) pada kedelai dapat menekan intensitas penyakit karat hingga $68 \%$ di rumah kaca, dan $17 \%$ di lapangan (Sumartini, 2010).

Akhir-akhir ini harga minyak cengkeh semakin mahal, pencampuran dengan bahan nabati lain sangat dimungkinkan supaya bahan baku produk fungisida nabati yang dibuat menjadi lebih murah. Ekstrak biji mimba selain digunakan untuk membunuh serangga hama juga sering digunakan sebagai penghambat perkembangan penyakit tanaman seperti pada sesame untuk menghambat perkembangan penyakit pasca panen yang disebabkan oleh cendawan Monilia fructicola, Penicillium expansum, Trichothesium roseum, Alternaria alternate (Wang et al., 2010). Selain itu ekstrak biji mimba dapat menghambat perkembangan cendawan Aspergillus flavus penghasil aflatoksin (Krishnamurthy \& Shashikala, 2006).

Biji tanaman Sapindus rarak banyak digunakan sebagai bahan pencuci (baju yang terbuat dari batik, peralatan dapur, hewan peliharaan). Lerak mengandung senyawa saponin, alkaloid, ateroid, dan triperten masingmasing sebesar $12 \% ; 1 \% ; 0,036 \%$ dan 0,029\% (Tommy, 2009). Selain itu ekstrak buah lerak juga berfungsi sebagai surfaktan nabati dan perekat (Chandra et al., 2012). Menurut Tsuzuki et al. (2007), buah lerak dapat menekan cendawan Candida parapsilapsis penyebab beberapa macam penyakit pada manusia.

Penelitian bertujuan untuk mendapatkan campuran minyak cengkeh, ekstrak mimba dan ekstrak lerak yang efektif untuk mengendalikan penyakit karat pada kedelai.

\section{METODE PENELITIAN}

Tempat dan Waktu. Penelitian ini terdiri dari dua tahap yaitu: (1) Efektivitas campuran minyak cengkeh dan ekstrak mimba untuk mengendalikan penyakit karat pada kedelai; penelitian tahap 1 dilakukan di Kebun Percobaan Kendalpayak, dan Laboratorium Mikologi, Balitkabi, pada musim kemarau tahun 2012, (2) Efektivitas campuran minyak cengkeh, ekstrak mimba dan ekstrak lerak untuk mengendalikan penyakit karat pada kedelai; penelitian tahap 2 dilakukan di Rumah Kaca dan Kebun Percobaan Kendalpayak pada musim kemarau 2013.

Efektivitas Campuran Minyak Cengkeh dan Ekstrak Mimba untuk Pengendalian Penyakit Karat pada Kedelai. Penelitian ini dilakukan dengan 
rancangan acak kelompok dengan empat ulangan, dengan perlakuan sebagai berikut:

1. Formula $1=$ Minyak cengkeh : ekstrak biji mimba $=50: 50(\mathrm{v}: \mathrm{v})$

2. Formula $2=$ Minyak cengkeh : ekstrak biji mimba $=60: 40(\mathrm{v}: \mathrm{v})$

3. Formula $3=$ Minyak cengkeh : ekstrak biji mimba $=70: 30(\mathrm{v}: \mathrm{v})$

4. Minyak cengkeh $(0,3 \%)$

5. Ekstrak biji mimba (5\%)

6. Air (sebagai kontrol)

Perbedaan antar perlakuan dihitung dengan menggunakan program $\mathrm{M}$-Stat $\mathrm{C}$ yang dikembangkan oleh Balai Riset IRRI (International Rice Research Institute) di Manila, Filipina.

Persiapan Tanaman. Benih kedelai varietas Burangrang ditanam pada plot-plot yang berukuran $4 \mathrm{x}$ $5 \mathrm{~m}$, dengan jarak tanam $15 \times 40 \mathrm{~cm}$. Setiap lubang tanam terdapat dua tanaman yang dipelihara. Dua minggu sebelum tanam, untuk penelitian ditanam dua baris benih kedelai varietas Burangrang di bagian pinggir mengeliling petak penelitian. Pada saat tanaman pinggir berumur 3 minggu dilakukan inokulasi penyakit karat pada tanaman pinggir sebagai sumber inokulum (dilakukan pada penelitian tahap 1 dan 2). Sehari sebelum inokulasi daun-daun terinfeksi di lapangan di bawa ke laboratorium untuk diinkubasi pada kelembaban tinggi. Suspensi spora (kerapatan $10^{4}$ ) diperoleh dengan merontokan spora dari daun-daun yang diinkubasi tersebut. Inokulasi dilakukan pada sore hari (kira-kira pukul 16.00-17.00).

Persiapan Bahan Nabati. Minyak cengkeh dibuat dengan cara penyulingan, (hasil penyulingan daun cengkeh murni sebanyak $3 \mathrm{ml}$ dicampur dengan satu liter air), sedangkan ekstrak mimba dibuat dengan cara menghaluskan $50 \mathrm{~g}$ biji mimba dengan "griener", kemudian dibuat suspensinya dengan menambahkan air sebanyak satu liter, dan diinkubasi selama 24 jam. Larutan disaring untuk mendapatkan residu yang bersih. Campuran larutan bahan nabati diberi Tween 20 sebayak dua tetes/L atau $0,28 \mathrm{ml} / \mathrm{L}$ pada saat akan disemprotkan. Penyemprotan dilakukan "knapsack sprayer", dengan interval 5 hari sekali, sebanyak tujuh kali penyemprotan. Perlakuan penyemprotan minyak cengkeh dan atau ekstrak biji mimba dilakukan pada saat tanaman berumur 30-65 hari.

Pengendalian hama selama penelitian dilakukan secara intensif. Untuk mengendalikan kutu kebul, dilakukan penyemprotan dengan Fipronil atau
Deltametrin dan ulat grayak dengan Lamda sihalotrin. Diusahakan penyemprotan hama tidak dilakukan pada hari yang sama dengan perlakuan untuk penelitian.

Pengamatan. Pengamatan intensitas penyakit karat dilakukan dengan memberi nilai (persentase) pada luas kanopi daun yang tertutupi oleh penyakit karat pada tanaman sampel, 10 tanaman sampel/plot. Berat brangkasan diukur dengan menimbang berat basah batang dan daun pada saat panen. Berat biji kering diukur dengan menimbang biji-biji yang sudah kering dan dikupas dari kulitnya. Jumlah polong hampa diukur dengan menghitung jumlah polong yang tidak berisi. Jumlah polong isi, diukur dengan menghitung jumlah polong ada isinya.

Efektivitas Campuran Minyak Cengkeh, Ekstrak Mimba dan Ekstrak Lerak untuk Pengendalian Penyakit Karat pada Kedelai. Uji efektivitas campuran minyak cengkeh, ekstrak mimba dan ekstrak lerak untuk pengendalian penyakit karat pada kedelai dilakukan dalam dua tahap yaitu di Rumah Kaca dengan menggunakan acak lengkap, dengan 10 ulangan. Benih kedelai varietas Burangrang (peka penyakit karat) ditanam pada pot-pot berisi tanah $5 \mathrm{~kg}$. Setiap perlakuan terdiri atas 10 pot, setiap pot terdiri atas dua tanaman. Tahap kedua dilakukan di Kebun Percobaan Kendalpayak dengan menggunakan benih kedelai varietas Burangrang ditanam pada plot-plot berukuran $4 \times 7,5 \mathrm{~m}$, jarak tanam $40 \times 15 \mathrm{~cm}$. Rancangan yang digunakan acak kelompok dengan 4 ulangan.

Perlakuannya baik di rumah kaca maupun di lapangan adalah sebagai berikut:

1. Formula $1=$ Campuran minyak cengkeh : ekstrak biji mimba : ekstrak lerak $=50: 30: 20$ (v:v:v)

2. Formula 2 = Campuran minyak cengkeh $:$ ekstrak biji mimba : ekstrak lerak $=60: 30: 10(\mathrm{v}: \mathrm{v}: \mathrm{v})$

3. Formula 3 = Campuran minyak cengkeh : ekstrak biji mimba : ekstrak biji lerak $=65: 30: 5$ (v:v:v)

4. Formula $4=$ Campuran minyak cengkeh : ekstrak biji mimba $=70: 30(\mathrm{v}: \mathrm{v})$

5. Minyak cengkeh

6. Ekstrak lerak (10\% w:v)

7. Ekstrak lerak ( $20 \%$ w:v)

8. Air (sebagai kontrol)

Persiapan Bahan Nabati. Minyak cengkeh diperoleh dari penyulingan daun cengkeh murni (dari pengrajin minyak cengkeh di Desa Watulimo, Kecamatan Watulimo, Kabupaten Trenggalek, Jatim) diambil $3 \mathrm{ml}$ dicampur dengan satu liter air. Ekstrak biji mimba dibuat dari $50 \mathrm{~g}$ biji mimba yang sudah dihaluskan ditambahkan 
satu liter air, kemudian direndam selama semalam, sedangkan ekstrak lerak dibuat dari buah lerak yang diiris-iris $100 \mathrm{~g} / \mathrm{L}$ air (10\%) dan $200 \mathrm{~g} / \mathrm{L}$ (20\%), buah lerak tersebut direndam selama semalam. Larutan disaring, dan air hasil rendaman tersebut (filtrat) siap untuk dicampurkan. Penyemprotan dilakukan pada saat tanaman berumur 30-65 hari setelah tanam, dengan interval waktu 5 hari. Pengendalian hama dilakukan secara intensif sepert pada penelitian pertama.

Parameter yang diamati: 1 . intensitas penyakit karat, 2. berat brangkasan, 3. jumlah polong bernas/isi, 4. jumlah polong hampa, 5 . berat biji kering, 6 . berat 100 biji. Pengamatan intensitas penyakit karat dilakukan pada lima titik secara diagonal di setiap plot, setiap titik dua tanaman sehingga setiap plot terdapat sepuluh tanaman sampel. Intensitas penyakit karat dihitung dengan memberi nilai (persentase) pada bagian tanaman yang tertutupi oleh penyakit karat.

\section{HASIL DAN PEMBAHASAN}

\section{Efektivitas Campuran Minyak Cengkeh dan Ekstrak Mimba untuk Pengendalian Penyakit} Karat pada Kedelai. Intensitas penyakit karat bervariasi antar perlakuan terendah adalah $18 \%$ dan tertinggi adalah $96 \%$. Intensitas penyakit karat pada petak tanpa bahan nabati cenderung lebih tinggi daripada yang diberi perlakuan bahan nabati. Pada umur 5, 6, dan 7 minggu setelah tanam, berturut-turut adalah 20, 59, dan $96 \%$. Intensitas karat pada awal pengamatan belum terlihat perbedaan antar perlakuan, sedangkan pada pengamatan ke dua, plot yang diberi Formula 2 (Minyak cengkeh : ekstrak biji mimba dicampur dengan perbandingan 60:40) berbeda nyata dengan plot tanpa penyemprotan. Pada akhir pengamatan intensitas penyakit karat terendah adalah pada perlakuan Formula 1 (minyak cengkeh : ekstrak mimba dicampur dengan perbandingan 50:50) dengan penghambatan sebesar 45\% dibandingkan dengan kontrol (Tabel 1).

Perkembangan penyakit karat sangat cepat menurut Koch et al. (1983), haustorium pertama tampak pada 24-48 jam setelah inokulasi. Uredinia (kantung uredospora) terbentuk 5-8 hari setelah infeksi oleh uredospora. Sedangkan menurut Bromfield \& Hartwig (1980), satu daun dengan beberapa bercak karat mungkin dapat mengandung uredospora yang sangat banyak dan akan menyebabkan epidemik. Setiap bercak memproduksi rata-rata lebih dari 12.000 uredospora dalam 4-6 minggu.

Perkembangan penyakit karat pada plot yang disemprot dengan mimba saja atau dengan minyak cengkeh saja sangat cepat dari 5 , ke 6 , dan 7 minggu setelah tanam, namun ketika dikendalikan dengan Formula 1 (minyak cengkeh : ekstrak mimba dicampur dengan perbandingan 50:50), maka perkembangan penyakit karat semakin lama (Tabel 1). Mekanisme penghambatan spora oleh bahan nabati cengkeh adalah dinding sel spora mengalami lisis (Sumartini, 2010). Pada umumnya pengendalian penyakit dengan menggunakan bahan nabati menekan perkembangan penyakit hingga 60\% (Kardinan, 2004), hal ini disebabkan oleh propagul yang berada di dalam jaringan tanaman tidak seluruhnya mati $(100 \%)$.

Berat brangkasan antar perlakuan secara statistik tidak berbeda nyata, namun terdapat kecenderungan bahwa plot yang disemprot dengan air saja mempunyai

Tabel 1. Intensitas serangan penyakit karat pada plot yang diberi beberapa macam perlakuan (KP Kendalpayak, MK 2012)

\begin{tabular}{llccc}
\hline \multirow{2}{*}{ No } & \multirow{2}{*}{ Perlakuan } & \multicolumn{2}{c}{ Intensitas penyakit karat (\%) pada umur } \\
\cline { 3 - 5 } & & $5 \mathrm{mst}(\mathrm{tn})$ & $6 \mathrm{mst}$ & $7 \mathrm{mst}$ \\
\hline 1 & Formula 1 & 23,25 & $41,50 \mathrm{ab}$ & $52,00 \mathrm{c}$ \\
2 & Formula 2 & 18,00 & $40,25 \mathrm{~b}$ & $72,13 \mathrm{~b}$ \\
3 & Formula 3 & 22,50 & $58,13 \mathrm{a}$ & $93,88 \mathrm{a}$ \\
4 & Minyak cengkeh (0,3\%) & 23,63 & $54,75 \mathrm{ab}$ & $93,75 \mathrm{a}$ \\
5 & Ekstrak mimba (5\%) & 19,25 & $40,25 \mathrm{~b}$ & $67,13 \mathrm{~b}$ \\
6 & Air (sebagai kontrol) & 20,00 & $58,75 \mathrm{a}$ & $95,88 \mathrm{a}$ \\
\hline & Kk (\%) & 27,30 & 23,56 & 12,04 \\
& BNT 0,05 & 8,67 & 17,38 & 14,36 \\
\hline
\end{tabular}

Formula 1= Minyak cengkeh : ekstrak biji mimba (50:50); Formula $2=$ minyak cengkeh : ekstrak biji mimba (60:40); Formula $3=$ minyak cengkeh $:$ ekstrak biji mimba $=70: 30 . \mathrm{MK}=$ Musim kering. $\mathrm{mst}=$ minggu setelah tanam, $\mathrm{tn}=$ tidak berbeda nyata. 
berat brangkasan yang lebih besar. Berat biji kering juga tidak berbeda nyata, dan ada kecenderungan bahwa pada plot yang diberi perlakuan minyak cengkeh saja dan plot pembanding memiliki berat biji kering lebih rendah daripada petak yang diberi perlakuan lainnya (Tabel 2).

Penyakit karat juga berpengaruh terhadap biji (kualitas maupun kuantitas), serangan penyakit karat yang parah akan mengakibatkan biji-biji menjadi keriput, atau polong kosong tidak berisi (Sudjono, 1977). Pengendalian penyakit karat akan meningkatkan jumlah polong yang bernas atau berisi. Jumlah polong isi tertinggi adalah pada plot yang disemprot dengan Formula 2 ( Minyak cengkeh : ekstrak biji mimba dengan perbandingan 60:40), dengan peningkatan sebesar $60 \%$.

Hasil biji kering antar perlakuan secara statistik juga tidak terdapat perbedaan antar perlakuan (Tabel 2), namun terdapat kecenderungan bahwa pengendalian penyakit karat dengan Formula 2 (Minyak cengkeh : ekstrak biji mimba dengan perbandingan 60:40) tersebut setidaknya dapat memperbaiki kualitas hasil dan dapat mencegah kehilangan hasil sebesar $0,350 \mathrm{~kg}$ atau $20 \%$.

\section{Efektivitas Campuran Minyak Cengkeh, Ekstrak Mimba dan Ekstrak Lerak untuk Pengendalian Penyakit Karat pada Kedelai. Pada pengamatan umur} $5,6,7$, dan 8 minggu setelah tanam intensitas penyakit karat masing-masing berkisar 14-36, 15- 48, 21-50, dan 22-50\%. Pada empat kali pengamatan secara konsisten Formula 1 (Campuran minyak cengkeh : ekstrak biji mimba : ekstrak lerak $=50: 30: 20$ ) dan Formula 2 (Campuran minyak cengkeh : ekstrak biji mimba : ekstrak lerak $=60: 30: 10$ ) lebih unggul dari perlakuan lainnya dan tanpa perlakuan (Tabel 3).
Supaya diperoleh larutan yang homogen, penyemprotan bahan nabati biasanya digunakan Tween 20 sebagai perata (surfaktan kimiawi). Pada penelitian ini, dengan menggunakan ekstrak lerak (sebagai pengganti Tween 20) larutan menjadi homogen, dan larutan dapat menempel pada permukaan daun.

Pada pengamatan umur $8,9,10$ minggu setelah tanam masing-masing berkisar 52-76; 54-90 dan 9098\%. Pada pengamatan pertama, intensitas penyakit karat pada semua plot yang diberi perlakuan bahan nabati berbeda nyata dengan tanpa perlakuan dengan penghambatan sebesar 20-25\% (Tabel 3). Hasil penelitian sebelumnya menunjukkan bahwa pencampuran minyak cengkeh dan ekstrak mimba dengan perbandingan 50:50 dapat menghambat perkembangan penyakit karat sebesar $45 \%$ dan mencegah kehilangan polong isi sebesar $20 \%$ dibandingkan dengan penyemprotan air saja.

Perlakuan Formula 2 (campuran bahan nabati cengkeh, mimba, dan lerak 60:30:10) efektif mengendalikan penyakit karat pada saat tanaman kedelai berumur 7, 8, dan 9 minggu, dengan penghambatan intensitas penyakit karat dibandingkan dengan tanpa perlakuan pada saat tanaman berumur 9 minggu berkisar 18-28\% di rumah kaca dan 19-24\% di lapangan (Tabel 4). Pada awalnya lerak digunakan untuk membuat campuran minyak cengkeh dan ekstrak biji mimba menjadi homogen, untuk memudahkan aplikasi di lapangan. Campuran minyak cengkeh dan ekstrak mimba kurang efektif menghambat perkembangan penyakit karat kedelai, diduga saponin yang terkandung di dalam lerak menetralisir eugenol yang terkandung di

Tabel 2. Berat brangkasan, berat biji/plot, jumlah polong isi, jumlah polong hampa (KP Kendalpayak, MK 2012)

\begin{tabular}{llcccc}
\hline No & Perlakuan & $\begin{array}{c}\text { Berat basah } \\
\text { brangkasan } \\
\text { /plot }(\mathrm{g}) \mathrm{tn}\end{array}$ & $\begin{array}{c}\text { Berat biji } \\
\text { kering/plot } \\
(\mathrm{kg})\end{array}$ & $\begin{array}{c}\text { Jumlah } \\
\text { polong } \\
\text { Isi/plot }\end{array}$ & $\begin{array}{c}\text { jumlah polong } \\
\text { hampa/plot } \\
\text { (tn) }\end{array}$ \\
\hline 1 & Formula 1 & 7737,5 & $1,795 \mathrm{a}$ & $13,65 \mathrm{ab}$ & 7,88 \\
2 & Formula 2 & 7525,0 & $1,725 \mathrm{a}$ & $14,90 \mathrm{a}$ & 9,70 \\
3 & Formula 3 & 7737,5 & $1,750 \mathrm{a}$ & $11,20 \mathrm{~b}$ & 9,54 \\
4 & Minyak cengkeh (0,3\%) & 7787,5 & $1,250 \mathrm{a}$ & $10,90 \mathrm{~b}$ & 7,15 \\
5 & Ekstrak mimba (5\%) & 7625,0 & $1,750 \mathrm{a}$ & $12,60 \mathrm{ab}$ & 7,76 \\
6 & Air (sebagai kontrol) & 8250,0 & $1,375 \mathrm{a}$ & $10,85 \mathrm{~b}$ & 7,90 \\
\hline & Kk (\%) & 8,79 & 3,41 & 3,16 & 41,99 \\
& BNT 0,05 & 1030,10 & 0,405 & 16,99 & 5,27 \\
\hline
\end{tabular}

Formula $1=$ minyak cengkeh : ekstrak biji mimba (50:50); Formula $2=$ minyak cengkeh : ekstrak biji mimba (60:40); Formula 3= minyak cengkeh $:$ ekstrak biji mimba $=70: 30 . \mathrm{MK}=$ Musim kering. $\mathrm{mst}=$ minggu setelah tanam, $\mathrm{tn}=$ tidak berbeda nyata. Plot $=4 \times 5 \mathrm{~m}$, $\mathrm{tn}=$ tidak berbeda nyata; $\mathrm{MK}=$ Musim kering. 
dalam minyak cengkeh dan azadirachtin yang terkandung di dalam ekstrak mimba,

Penggunaan ekstrak lerak secara tunggal dengan konsentrasi $10 \%$ dapat menghambat intensitas penyakit karat sebesar $15 \%$, dan mendapatkan berat biji kering yang lebih tinggi daripada perlakuan lainnya, yaitu sebesar 1687,50 g, dan sama dengan Formula 2 sebesar $1675 \mathrm{~g}$ (Tabel 5). Berat biji kering pada plot yang diberi perlakuan ekstrak lerak (10\%) sama dengan plot yang diberi perlakuan Formula 2 dan secara nyata lebih tinggi daripada perlakuan lainnya dan kontrol (Tabel 5). Hasil tersebut selaras dengan intensitas penyakit karat, didapatkan bahwa semakin tinggi intensitas penyakit karat, maka semakin rendah hasil panen (berat biji). Dengan perlakuan Formula 2 atau ekstrak lerak 10\%, kehilangan hasil yang dapat dicegah sebesar $0,2 \mathrm{~kg}$ atau $12 \%$.

Penggunaan ekstrak lerak selain efektif juga efisien. Saat ini harga lerak di pasaran sekitar Rp 5000,00 $/ \mathrm{kg}$, penggunaannya $10 \%(\mathrm{~b} / \mathrm{v})$, sementara harga minyak cengkeh sebesar Rp 175.000,00/liter, penggunaannya 3 $\mathrm{cc} / \mathrm{L}(\mathrm{v} / \mathrm{v})$, dimana satu liter minyak cengkeh dapat digunakan untuk 300 liter larutan. Pembelian lerak sebesar Rp 175.000,00 akan mendapatkan 35 kg lerak, cukup untuk pembuatan 3500 liter larutan. Dari hitungan tersebut, lerak lebih ekonomis daripada minyak cengkeh,

Tabel 3. Intensitas penyakit karat di rumah kaca (MK 2013)

\begin{tabular}{clllll}
\hline No & Perlakuan & $36 \mathrm{hst}$ & $42 \mathrm{hst}$ & $49 \mathrm{hst}$ & $56 \mathrm{hst}$ \\
\hline 1 & Formula 1 & $14,0 \mathrm{~d}$ & $15,5 \mathrm{~d}$ & $21,0 \mathrm{~d}$ & $22,0 \mathrm{c}$ \\
2 & Formula 2 & $16,0 \mathrm{~cd}$ & $17,5 \mathrm{~cd}$ & $21,5 \mathrm{~d}$ & $23,5 \mathrm{c}$ \\
3 & Formula 3 & $16,5 \mathrm{~cd}$ & $27,5 \mathrm{~b}$ & $31,0 \mathrm{bcd}$ & $32,0 \mathrm{bc}$ \\
4 & Formula 4 & $16,5 \mathrm{~cd}$ & $26,5 \mathrm{bc}$ & $27,5 \mathrm{~cd}$ & $26,0 \mathrm{c}$ \\
5 & Minyak cengkeh & $21,5 \mathrm{bc}$ & $33,5 \mathrm{~b}$ & $41,0 \mathrm{ab}$ & $44,0 \mathrm{ab}$ \\
6 & Ekstrak lerak (10\%) & $20,5 \mathrm{bc}$ & $30,5 \mathrm{~b}$ & $38,0 \mathrm{abc}$ & $42,0 \mathrm{ab}$ \\
7 & Ekstrak lerak (20\%) & $25,5 \mathrm{~b}$ & $35,0 \mathrm{~b}$ & $43,5 \mathrm{a}$ & $46,0 \mathrm{a}$ \\
8 & Air (sebagai kontrol) & $36,0 \mathrm{a}$ & $48,0 \mathrm{a}$ & $50,0 \mathrm{a}$ & $50,5 \mathrm{a}$ \\
\hline & BNT 0,05 & 6,48 & 9,16 & 12,04 & 12,35 \\
\hline
\end{tabular}

Angka yang diikuti oleh huruf sama dalam satu kolom menunjukkan tidak berbeda nyata pada BNT 0,05 . Formula $1=$ campuran minyak cengkeh : ekstrak biji mimba : ekstrak lerak (50:30:20); Formula $2=$ campuran minyak cengkeh : ekstrak biji mimba : ekstrak lerak (60:30:10); Formula 3=campuran minyak cengkeh : ekstrak biji mimba : ekstrak biji lerak (65:30:5); Formula 4= campuran minyak cengkeh : ekstrak biji mimba (70:30). MK= Musim kering.

Tabel 4. Intensitas penyakit karat (KP Kendalpayak, MK 2013)

\begin{tabular}{llccc}
\hline \multirow{2}{*}{ No } & \multirow{2}{*}{ Perlakuan } & \multicolumn{3}{c}{ Intensitas penyakit karat (\%) } \\
\cline { 3 - 5 } & & 50 hst & 67 hst (tn) & 74 hst (tn) \\
\hline 1 & Formula 1 & $56,60 \mathrm{a}$ & 84,00 & 89,80 \\
2 & Formula 2 & $57,90 \mathrm{a}$ & 88,20 & 96,00 \\
3 & Formula 3 & $57,20 \mathrm{a}$ & 86,20 & 93,90 \\
4 & Formula 4 & $50,40 \mathrm{a}$ & 88,80 & 95,60 \\
5 & Minyak cengkeh & $61,30 \mathrm{a}$ & 88,90 & 95,60 \\
6 & Ekstrak lerak (10\%) & $52,50 \mathrm{a}$ & 88,40 & 94,40 \\
7 & Ekstrak lerak (20\%) & $76,10 \mathrm{~b}$ & 88,90 & 96,60 \\
8 & Air (kontrol) & 15,61 & 90,50 & 5,50 \\
\hline & BNT 0,05 & 5,26 & 5,91 \\
\hline
\end{tabular}

Angka yang diikuti oleh huruf sama dalam satu kolom menunjukkan tidak berbeda nyata pada BNT 0,05; tn = tidak berbeda nyata. Formula $1=$ campuran minyak cengkeh : ekstrak biji mimba : ekstrak lerak $=50: 30: 20$; Formula $2=$ campuran minyak cengkeh : ekstrak biji mimba : ekstrak lerak= 60:30:10; Formula 3= campuran minyak cengkeh : ekstrak biji mimba : ekstrak lerak = 65:30:5; Formula 4= campuran minyak cengkeh $:$ ekstrak biji mimba $=70: 30$. $\mathrm{MK}=$ Musim kering. 
Tabel 5. Komponen hasil kedelai pada tanaman yang diberi perlakuan bahan nabati (KP Kendalpayak, MK 2013)

\begin{tabular}{cccccc}
\hline Perlakuan & $\begin{array}{c}\text { Jumlah } \\
\text { tanaman (tn) }\end{array}$ & $\begin{array}{c}\text { Berat brangkasan } \\
\text { basah }(\mathrm{g})\end{array}$ & $\begin{array}{c}\text { Berat brangkasan } \\
\text { kering }(\mathrm{g})\end{array}$ & $\begin{array}{c}\text { Berat biji } \\
\text { kering }(\mathrm{g})\end{array}$ & $\begin{array}{c}\text { Berat 100 butir } \\
(\mathrm{g})\end{array}$ \\
\hline 1 & 213,75 & $5350,00 \mathrm{bc}$ & $3725,00 \mathrm{~b}$ & $1625,00 \mathrm{ab}$ & $16,13 \mathrm{abc}$ \\
2 & 233,75 & $6012,50 \mathrm{a}$ & $4337,50 \mathrm{a}$ & $1675,00 \mathrm{a}$ & $16,38 \mathrm{ab}$ \\
3 & 203,75 & $5237,50 \mathrm{c}$ & $3700,00 \mathrm{~b}$ & $1537,50 \mathrm{ab}$ & $16,00 \mathrm{bc}$ \\
4 & 217,00 & $5525,00 \mathrm{abc}$ & $3887,50 \mathrm{ab}$ & $1637,50 \mathrm{ab}$ & $16,13 \mathrm{abc}$ \\
5 & 219,50 & $5875,00 \mathrm{ab}$ & $4275,00 \mathrm{ab}$ & $1600,00 \mathrm{ab}$ & $15,50 \mathrm{~cd}$ \\
6 & 195,75 & $5612,50 \mathrm{abc}$ & $3925,00 \mathrm{ab}$ & $1687,50 \mathrm{a}$ & $16,88 \mathrm{a}$ \\
7 & 230,00 & $5362,50 \mathrm{bc}$ & $3762,50 \mathrm{ab}$ & $1600,00 \mathrm{ab}$ & $16,00 \mathrm{bc}$ \\
8 & 216,25 & $5237,50 \mathrm{c}$ & $3750,00 \mathrm{ab}$ & $1487,50 \mathrm{~b}$ & $15,00 \mathrm{~d}$ \\
\hline BNT 0,05 & 38,38 & 570,5 & 600,5 & 172,4 & 0,915 \\
\hline Anta
\end{tabular}

Angka yang diikuti oleh huruf sama dalam satu kolom menunjukkan tidak berbeda nyata pada BNT 0,$05 ; \mathrm{tn}=$ tidak berbeda nyata. Formula $1=$ campuran minyak cengkeh : ekstrak biji mimba : ekstrak lerak (50:30:20); Formula $2=$ campuran minyak cengkeh : ekstrak biji mimba : ekstrak lerak (60:30:10); Formula $3=$ campuran minyak cengkeh : ekstrak biji mimba : ekstrak biji lerak (65:30:5); Formula $4=$ campuran minyak cengkeh : ekstrak biji mimba (70:30); 5= minyak cengkeh; 6= lerak 10\%; 7= lerak 20\%; 8= air (pembanding); MK= Musim kering.

dari segi ketersediaan lerak lebih mudah didapatkan di pasar-pasar, dan tidak melalui penyulingan.

\section{SIMPULAN}

Campuran minyak cengkeh dan ekstrak biji mimba dengan perbandingan 60/40 (v/v) merupakan campuran efektif untuk mengendalian penyakit karat pada kedelai dapat menekan intensitas penyakit karat hingga $45 \%$, meningkatkan polong isi sebesar $37 \%$, dan mencegah kehilangan hasil sebesar $20 \%$.

Campuran minyak cengkeh, ekstrak biji mimba, dan lerak dengan perbandingan 50/30/20 (v/v/v) mampu menekan intensitas penyakit karat hingga 28\% dan 24\% masing-masing di rumah kaca dan lapang, serta menekan kehilangan hasil hingga $12 \%$.

\section{SANWACANA}

Penulis mengucapkan terima kasih dan penghargaan kepada Saudara Hari Atim Pujiono yang telah membantu pelaksanaan penelitian di lapang dan rumah kaca.

\section{DAFTAR PUSTAKA}

Bromfield KR \& Hartwig EE. 1980. Resistance to soybean rust and mode of inheritance. Crop Sci. 20(2): 254-255.
Chandra IK, Ju YH, Ayucitra A, \& Ismadji S. 2012. Evans blue removal from wastewater by rarasaponin-bentonite. Int. J. Environ. Sci. Technol. 10(2): 359-370.

Direktorat Akabi. 2013. Soybean production net only $35 \%$. http:// tanamanpangan.pertanian.go.id/akabii/ berita_142_produksi_kedelai_baru_ terpenuhi_35\%_htm.

Kardinan A. 2004. Pestisida Nabati, Ramuan dan Aplikasi. Penebar Swadaya. Jakarta.

Koch E, Ebrahim-Nesbat F, \& Hope HH. 1983. Light and electron microscopic studies on the development of soybean rust (Phakopsora pachyrhizi Syd.) in susceptible soybean leaves (Glycine max). Phytopathologische Zeitschrift 106(3): 302-320.

Krishnamurthy YL \& Shashikala J. 2006. Inhibition of aflatoxin $\mathrm{B}_{1}$ production of Aspergillus flavus, isolated from soybean seeds by certain natural plant products. Lett. Appl. Microbiol. 43(5): 469474.

Manohara D, Wahyuno D \& Sukamto. 1994. Pengaruh tepung dan minyak cengkeh terhadap Phytophtora, Rigidoporus, dan Sclerotium. Hlm: 19-27. Prosiding Seminar Hasil Penelitian dalam Rangka Pemanfaatan Pestisida nabati. 1-2 Desember 1993. Bogor. 
Miles MR, Frederick RD, \& Hartman GL. 2003. Soybean Rust: Is the US Soybean Crop at Risk? http://www.apsnet.org/publications/ apsnetfeatures/Pages/SoybeanRust.aspx. Diakses tanggal 22 July 2008.

Semangun H. 2004. Penyakit-Penyakit Tanaman Pangan di Indonesia. Gadjah Mada University Press. Yogyakarta.

Sinclair JB \& MC Shurtleff. 1980. Compendium of Soybean Diseases. The American Phytopathological Society Press. USA.

Sudjono S. 1977. Perkembangan penyakit karat (Pakopsora pachyrhizi) pada kedelai. Tesis. Institut Pertanian Bogor, Bogor.

Sudjono S, Mukelar Amir, \& Roechan M. 1985. Penyakit karat dan penanggulangannya. Dalam: Sadikin Somaatmadja, M. Ismunadji, Sumarno, Mahyuddin Syam, S.O Manurung, \& Yuswadi (Eds.). Kedelai. Pusat Penelitian Tanaman Pangan. Bogor.

Sumartini. 2007. Efektivitas ekstrak bahan nabati untuk pengendalian penyakit karat (Phakopsora pachyrhizi) pada kedelai. J. Ilmu Pertanian Mapeta 9(2): 70-75.
Sumartini. 2010. Penyakit karat pada kedelai dan cara pengendaliannya yang ramah lingkungan. $J$. Penelitian dan Pengembangan Pertanian 29(3): 107-112.

Towaha J. 2012. Manfaat eugenol cengkeh dalam berbagai industri di Indonesia. Perspektif 11(2): $79-90$

Tommy. 2009. Lerak/Klerak/Sapindus rarak. http:// sapinduslerak.wordpress.com. Diakses tanggal_12 April 2012.

Tsuzuki JK, Svidzinski TIE, Shinobu CS, Silva LFA, Rodrigues-Filho E, Cortez DAG, \& Ferreira ICP. 2007. Antifungal activity of extracts and saponins from Sapindus saponaria L. An. Acad. Bras. Ciênc. 74(6): 577-583.

Wang J, Li J, Cao J, \& Jiang W. 2010. Antifungal activities of neem (Azadirachta indica) seed kernel extract on postharvest diseases in fruit. Afr. J. Microbiol. Res. 4(11): 1100-1104. 